\title{
Antibacterial Investigation using Spectrophotometric Assay of the Polar Leaf Extracts of Ficus capensis (Moraceae)
}

\author{
Achimugu Dickson Musa ${ }^{1}$, Sandra Tombiah Dorgu ${ }^{1}$, Ogbiko Cyril2*, Jeremiah Ikko ${ }^{1}$, Muhammad Hausa Shuaib ${ }^{1}$, \\ Okwesili Fred Chiletugo Nwodo ${ }^{3}$, Philipp Krastel ${ }^{4}$
}

\begin{abstract}
This study was designed to explore new antibacterial agent(s) from the defatted methanol and water extracts of Ficus capensis. The extracts were obtained using various solvents, namely, cyclohexane, dichloromethane, methanol, and water by serial exhaustive extraction, after which both extracts were challenged with pure clinical isolates of Escherichia coli, Pseudomonas aeruginosa, Klebsiella pneumoniae, Staphylococcus aureus, Acinetobacter baumannii, and Burkolderia cepacia viz-a-viz standard antibiotics of chloramphenicol, gentamicin, and amoxicillin at $25 \mu \mathrm{g} / \mathrm{ml}, 50 \mu \mathrm{g} / \mathrm{ml}$, and $100 \mu \mathrm{g} / \mathrm{ml}$ concentrations using spectrophotometric method. Using the zone of inhibition as an inhibitory parameter, both extracts of $F$. capensis showed promising antimicrobial activity in a concentration-dependent manner comparable to the standard antibiotics for all tested microorganisms. This research holds promise for the exploration of various potentially active secondary metabolites which would help in developing pharmaceuticals, especially antibacterial drugs, for combating common microbial infections. This validates the use of the plant leaves in the treatment of broad-spectrum microbial infections in ethnomedicine.
\end{abstract}

Keywords: Antimicrobial, Defatted extracts, Ficus capensis, Spectrophotometric

Asian Pac. J. Health Sci., (2020); DOI: 10.21276/apjhs.2020.7.3.6

\section{INTRODUCTION}

Ficus capensis, a native of tropical Africa and the Cape Islands, belongs to the family Moraceae. The plant is a deciduous tree with spreading roots and branches and broad green leaves. It is known as "uwaryara" in Hausa, "opoto" in Yoruba, "rima bichehi" in Fulani, "akokoro" in Igbo, and "obada" in Edo. ${ }^{[1,2]}$ Conventionally, preparations from the plant parts are used in the treatment of dysentery, edema, epilepsy, chest ailments, leprosy, tuberculosis, anemia, and rickets in infants among others. ${ }^{[2-5]}$ Aside its tradomedicinal applications, F. capensis has been reported based on modern scientific investigations to possess anti-sickling, ${ }_{,}^{[6,7]}$ antibacterial, ${ }^{[4]}$ antiabortifacient, ${ }^{[8]}$ immune-stimulatory, ${ }^{[9]}$ antidiarrheal, ${ }^{[10]}$ antioxidant, ${ }^{[11]}$ pro-fertility in treating azoospermia, ${ }^{[12]}$ as well as its leaf, stem, and roots recently established to manage and treat typhoid disease-causing Salmonella typhi organism. ${ }^{[13]}$

The world over relies one way or the other on medicinal plants as alternative sources of drugs for the treatment of several disease conditions ${ }^{[14]}$ as a result of the fact that majority of the populations, especially in developing countries like Nigeria experience inadequate contacts with orthodox health-care facilities, the nonavailability and unbearable side effects associated with synthetic drugs. ${ }^{[2]}$ Phytochemicals are naturally occurring compounds in medicinal plants which offer defense mechanism and protection from various diseases. ${ }^{[15]}$ They are active secondary metabolites playing an important role in the prevention of various diseases conditions. ${ }^{[14]}$

This study attempts to give scientific credence or otherwise to the claim that $F$. capensis leaf as used in Igala traditional medicine have positive effect for the treatment of febrile ailments and infective disorders, hence as part of a wider study, the broadspectrum antibacterial activities of the polar extracts of the plant were investigated.
'Department of Biochemistry, Ibrahim Badamasi Babangida University, Lapai, Nigeria

${ }^{2}$ Department of Pure and Applied Chemistry, Usmanu Danfodiyo University, Sokoto, Nigeria

${ }^{3}$ Drug and Diet Research, University of Mker, Mker, Nigeria

${ }^{4}$ Centre for Proteomic Chemistry, Novartis Institute for BioMedical Research, Basel, Switzerland

Corresponding Author: Ogbiko Cyril, Department of Pure and Applied Chemistry, Usmanu Danfodiyo University, Sokoto, Nigeria. Tel.: +234-808-0398-933. Email: cyril.ogbiko@udusok.edu.ng

How to cite this article: Musa AD, Dorgu ST, Cyril O, Ikko J, Shuaib MH, Nwodo OFC, Krastel P. Antibacterial Investigation using Spectrophotometric Assay of the Polar Leaf Extracts of Ficus capensis (Moraceae). Asian Pac. J. Health Sci., 2020; 7(3):23-26

Source of support: Nil

Conflict of interest: None

Received: 14/01/2020 Revised:05/06/2020 Accepted: 25/06/2020

\section{Materials and Methods}

\section{Plant Collection and Authentication}

Healthy and matured F. capensis leaves were collected from Anyigba town in North-Central Nigeria. They were identified by Prof. COC Agwu of the Biological Sciences Department, Kogi State University, Anyigba, Nigeria. They were collected in bags before them being washed with running tap water to remove earthy impurities. They were shade dried at room temperature for 2 weeks before being pulverized using high-speed Creston mechanical grinder. The pulverized samples were stored in airtight glass container until ready to use. 


\section{Collection of Microorganisms}

Clinical microbial strains used in this study (Escherichia coli, Pseudomonas aeruginosa, Klebsiella pneumoniae, Staphylococcus aureus, Acinectobacter baumanii, and Burkolderia cepacia) from different specimens of patients referred to the Medical Microbiology Department, University of Lagos Teaching Hospital, Lagos State Nigeria. The bacteria were characterized to species level using different laboratory procedures, including gram's stain, cultural characterization, and biochemical tests, notably Indole, Methyl red, Vougues Proskeaur, Catalase, Citrate utilization, and coagulase tests. ${ }^{[16,17]}$ The isolates were maintained on nutrient agar slants at $4^{\circ} \mathrm{C}$ until ready for use.

\section{Standard Antibiotics Employed for the Study}

Chloramphenicol (Kuka Consumer Healthcare, Nigeria), Gentamicin (Jinhing Pharmaceuticals, China), and Amoxicillin (Clarion Medicals, Nigeria) were the employed reference drugs employed for the study purchased from reputable drug outlets.

\section{Extracts Preparation}

The defatted methanol extract of $F$. capensis ( $F C_{-} \mathrm{dMeOH}$ ) was obtained by cold macerating $300 \mathrm{~g}$ of the pulverized plant sample within $3 \mathrm{~L}$ of cyclohexane for $24 \mathrm{~h}$ with the resulting residue after filtration subjected to further cold maceration sequentially using $3 \mathrm{~L}$ of dichloromethane and methanol for $24 \mathrm{~h}$ each. The residue of the methanol extraction was cold macerated in distilled water, allowed to stand for $24 \mathrm{~h}$ and filtered with Whatmann No. 1 filter paper. The filtrate was concentrated to dryness using a freeze dryer. The yield of the crude extract $\left(\mathrm{FC} \_\mathrm{dHOH}\right)$ was determined relative to the starting material. The extracts were kept in an airtight glass container and refrigerated at $-4^{\circ} \mathrm{C}$ until use.

\section{Preparation and Reconstitution of the Plant Extracts for Antibacterial Study}

The inocula were reconstituted and standardized according to the procedure described by Rajarkaruna et al. ${ }^{[18]}$ The FC_dMeOH and FC_dHOH were individually reconstituted by dissolving $1 \mathrm{mg}$ of the extract in $2 \mathrm{ml}$ of dimethyl sulfoxide (DMSO) to obtain a stock solution concentration of $0.5 \mathrm{mg} / \mathrm{ml}$. One milliliter of the stock solution was added to $4 \mathrm{ml}$ nutrient broth give a concentration of $100 \mu \mathrm{g} / \mathrm{ml}$. By double serial dilution, the concentrations of $50 \mu \mathrm{g} / \mathrm{ml}$ and $25 \mu \mathrm{g} / \mathrm{ml}$ were obtained. Twelve test tubes were sorted into two groups (FC_dMeOH and FC_dHOH) with each group having six test tubes, three for the test concentrations of $25 \mu \mathrm{g} / \mathrm{ml}, 50 \mu \mathrm{g} / \mathrm{ml}$, and $100 \mu \mathrm{g} / \mathrm{ml}$, respectively, while the other three test tubes were each for the standard antibiotics (positive control) prepared using the same concentration. The negative control was prepared by adding $1 \mathrm{ml}$ DMSO to $4 \mathrm{ml}$ nutrient broth.

\section{Antibacterial Screening}

The spectrophotometric method described by Banjara et al. ${ }^{[19],}$ as modified by Musa et al. ${ }^{[20]}$ was used to determine the antibacterial activity of the extracts.

\section{Statistical Analysis}

Data obtained from the study were subjected to a one-way analysis of variance, and variant means were separated post hoc using the least significant difference method. Statistical Package for the Social Sciences software, version 16.0, was used for the analysis. Significance was accepted at $P<0.05$.

\section{Results}

The kinetics of the optical densities of the microbial growth of the six test bacteria is as shown in Figure 1.

The results of the percentage inhibitions of the $\mathrm{FC} \_\mathrm{dMeOH}$ and $\mathrm{FC} \_\mathrm{dHOH}$ in comparison to the standard antibiotics when challenged with the test organisms at the different investigated concentrations are represented in Figures 2a-f.

\section{Discussion}

\section{Percentage Yield of the Extracts}

$12.30 \mathrm{~g}$ and $35.40 \mathrm{~g}$ of the methanol and aqueous extracts corresponding to a percentage yield of $4.1 \%$ and $11.8 \%$, respectively, were obtained for the extraction of the pulverized leaves of $F$. capensis. These results are comparable to the findings of Dickson et al. ${ }^{[13]}$ but higher than the $8.78 \%$ reported by Ayinde and Owolabi ${ }^{[2]}$ and Ayinde et al. ${ }^{[10]}$

\section{Antimicrobial Study}

The microbial strains growth and inhibitions when monitored spectrophotometrically were seen to increase on an hourly basis before peaking after $12 \mathrm{~h}$, the decline between 12 and $15 \mathrm{~h}$ before increasing during the $18 \mathrm{~h}$ monitoring period. The negative control which contained DMSO without the plant extract or standard antibiotics produced no inhibition of any of the test organisms at $12 \mathrm{~h}$ post-inoculation.

Both extracts exhibit an increase in the inhibition of all the microbial isolates in a dose-dependent manner. All the standard antibiotics exhibit a higher microbial inhibitions greater than both extracts when challenged with $E$. coli, P. aeruginosa and K. pneumoniae except for E. coli which exhibits a $100 \%$ inhibition at the highest concentration of $100 \mu \mathrm{g} / \mathrm{mL}$. This, however differs, from that of S. aureus, A. baumanii, and B. cepacia, where the standard antibiotics exhibit a higher inhibition than both extracts at the highest investigated concentration. The disparity between the activities of the extracts and the standard antimicrobial drugs may be due to the mixtures of bioactive compounds present in the extracts compared to the pure compound contained in the standard antibiotics. ${ }^{[14]}$ The antimicrobial activities of the extracts are in agreement with the report of Cooper et al. ${ }^{[21]}$ who reported

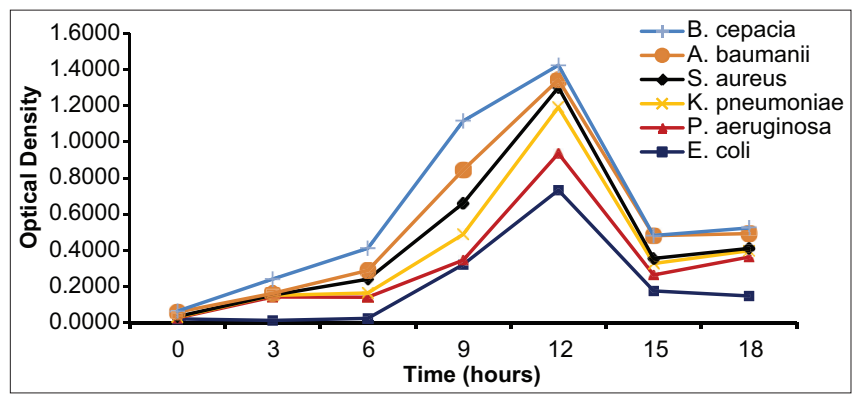

Figure 1: Growth rate of six bacteria using the measurement of their optical density at $540 \mathrm{~nm}$ 


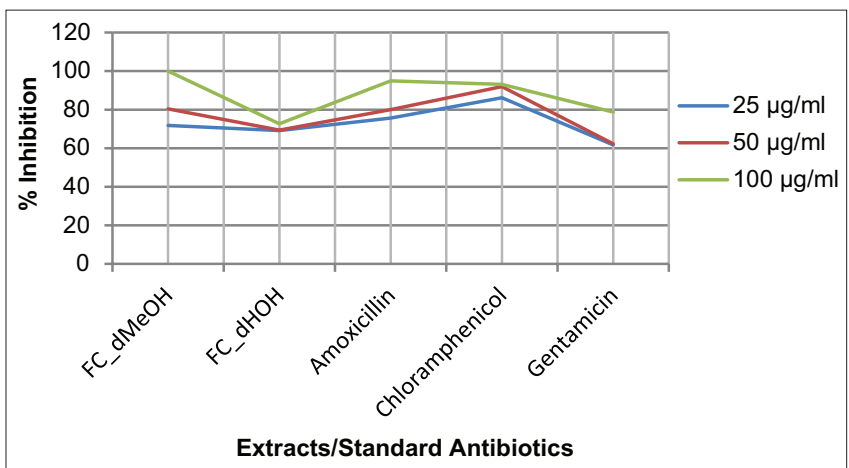

Figure 2a: Percentage inhibition of Escherichia coli when challenged with the plant extracts and the standard drugs at varying concentrations. FC_dMeOH: Defatted methanol extract of Ficus capensis, FC_dHOH: Defatted aqueous extract of Ficus capensis

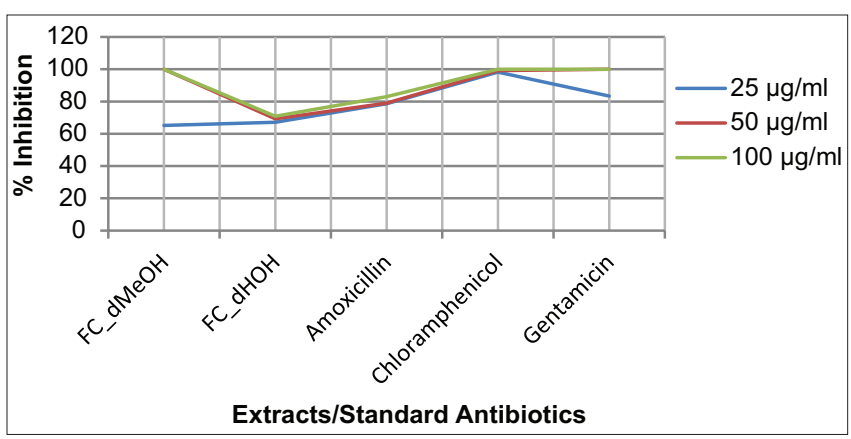

Figure 2b: Percentage inhibition of Pseudomonas aeruginosa when challenged with the plant extracts and the standard drugs at varying concentrations. FC_dMeOH: Defatted methanol extract of Ficus capensis, FC_dHOH: Defatted aqueous extract of Ficus capensis

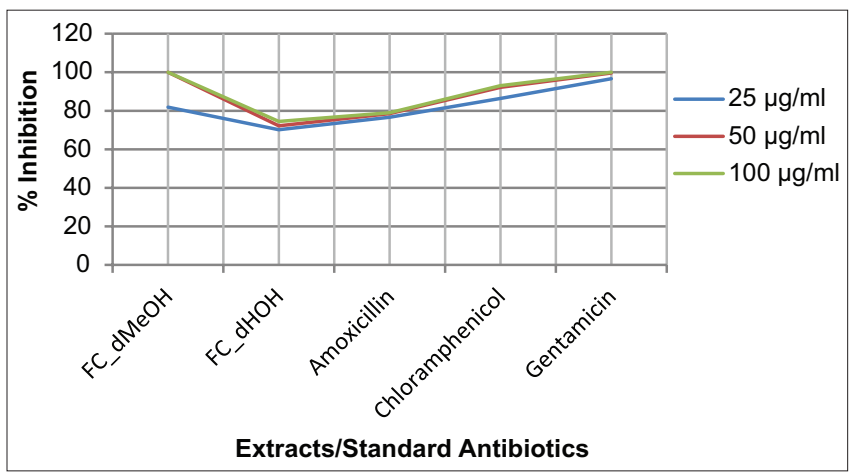

Figure 2c: Percentage inhibition of Klebsiella pnuemoniae when challenged with the plant extracts and the standard drugs at varying concentrations. FC_dMeOH: Defatted methanol extract of Ficus capensis, FC_dHOH: Defatted aqueous extract of Ficus capensis

that the presence of more group of phytochemical diversity gives synergic effects in many biological applications.

The phytoconstituents present in the leaves of the plant, as reported by Dickson et al. ${ }^{[13,19]}$ as well as Uzoekwe and Mohammed ${ }^{[22]}$ who confirms the presence of flavonoid, alkaloid, saponins, phenols, cardiac glycoside, terpenoid, steroids, and tannins. The presence of these phytochemicals in F. capensis leaf extracts has also been reported by many researchers ${ }^{[23-25]}$ to

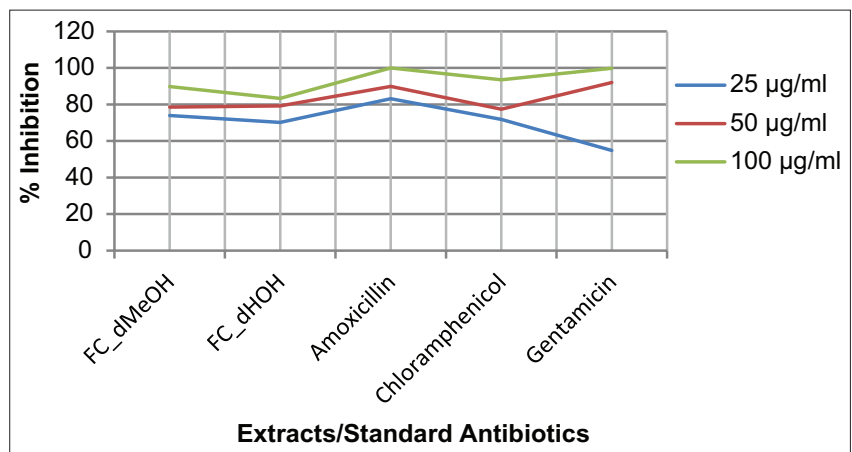

Figure 2d: Percentage inhibition of Staphylococcus aureus when challenged with the plant extracts and the standard drugs at varying concentrations. FC_dMeOH: Defatted methanol extract of Ficus capensis, FC_dHOH: Defatted aqueous extract of Ficus capensis

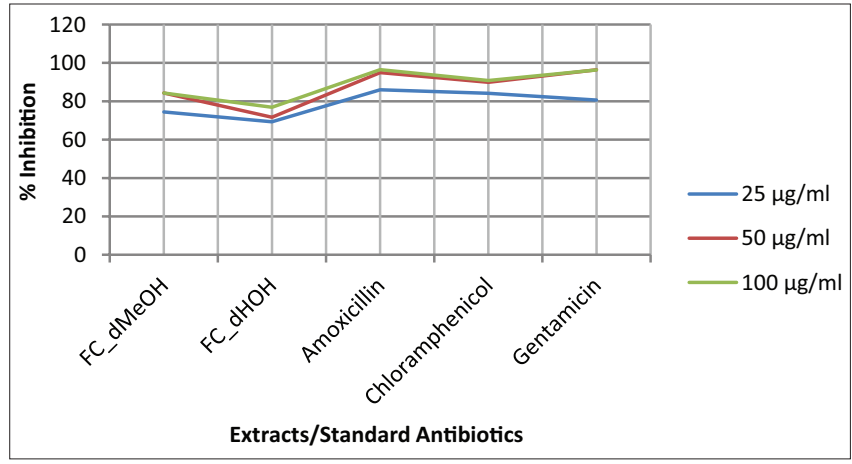

Figure 2e: Percentage inhibition of Acinectobacter baumanii when challenged with the plant extracts and the standard drugs at varying concentrations. FC_dMeOH: Defatted methanol extract of Ficus capensis, FC_dHOH: Defatted aqueous extract of Ficus capensis

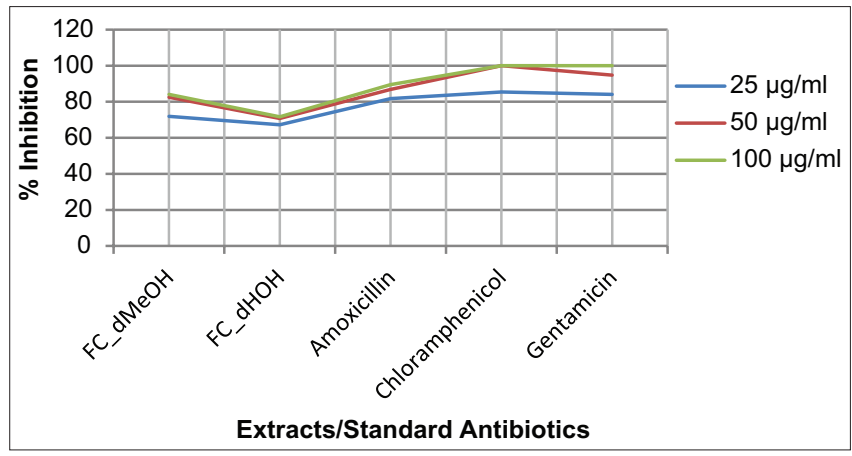

Figure 2f: Percentage inhibition of Burkolderia cepacia when challenged with the plant extracts and the standard drugs at varying concentrations. FC_dMeOH: Defatted methanol extract of Ficus capensis, FC_dHOH: Defatted aqueous extract of Ficus capensis

confer the therapeutic potentials of all medicinal plants. Alkaloids, saponins, and tannins specifically have been reported to inhibit bacterial growth as well as offer protection to plants from microbial infections. ${ }^{[2]}$ The leaves of the plant have been reported to exhibit remarkable inhibitory activities against the growth of enteric bacteria notably E. coli, B. subtilis, S. aureus, and Shigella species as reported by Oyeleke et al., ${ }^{[4]}$ François et al., ${ }^{[27]}$ and SolomonWisdom et al. ${ }^{[28]}$ 


\section{Conclusion}

The standard antibiotics showed a better antibacterial activity than both extracts thou not statistically significant. All tested concentrations of FC_dMeOH have a better antibacterial agent than FC_dHOH except when challenged with $P$. aeruginosa and S. aureus at $25 \mu \mathrm{g} / \mathrm{mL}$ and $25 \mu \mathrm{g} / \mathrm{mL}$, respectively. These reports in combination with the results of the present work may justify the use of the $F$. capensis leaves in the treatment of broadspectrum microorganisms in ethnomedicine as well as encourages researchers to do further in vitro and in vivo research that will explore the role of the bioactive constituents responsible for these activities as well as carry out studies at molecular level.

\section{ACKnOWLedgment}

The authors gratefully acknowledge Novartis Institute for BioMedical Research, Basel, Switzerland, for partly funding this research.

\section{References}

1. Gills LS. Ethnomedical Uses of Plants in Nigeria. Edo State, Nigeria: Uniben Press; 1992. p. 121.

2. Ayinde BA, Owolabi OJ. Effect of the aqueous extract of Ficus capensis Thunb. (Moraceae) leaf on gastrointestinal motility. J Pharmacogn Phytother 2009;1:31-5.

3. Ahmadu AA, Zezi AU, Yaro AH. Anti-diarrheal activity of the leaf extracts of Daniella oliveri Hutch and Dalz (Fabaceae) and Ficus sycomorus Miq (Moraceae). Afr J Tradit Complement Altern Med 2007;4:524-8.

4. Oyeleke SB, Dauda BE, Boye OA. Antibacterial activity of Ficus capensis. Afr J Biotechnol 2008;7:1414-7.

5. Adebayo-Tayo BC, Odeniyi AO. Phytochemical screening and microbial inhibitory activities of Ficus capensis. Afr J Biomed Res 2012;15:35-40.

6. Umeokoli BO, Onyegbule FA, Gugu TH, Igboeme SO. Evaluation of the erythropoietic and anti-sickling properties of Ficus capensis leaf extract in the treatment of anaemia. Planta Med 2013;79:79-89.

7. Mpiana PT, Mudogo V, Tshibangu DS, Kitwa EK, Kanangila AB, Lumbu JB, et al. Antisickling activity of anthocyanins from Bombax pentadrum, Ficus capensis, Zizyphus mucronata: Photo degradation effect. J Ethnopharmacol 2008;120:413-8.

8. Owolabi OJ, Nworgu ZA, Falodun A, Ayinde BA, Nwako CN. Evaluation of tocolytic activity of ethanol extracts of the stem bark of Ficus capensis Thunb. (Moraceae). Acta Pol Pharm Drug Res 2009;66:293-6.

9. Daikwo OA, Tende JA, Okey SM, Eze ED, Isa AS. The effect of aqueous extract of leaf of Ficus capensis Thunb (Moraceae) on in vivo leukocyte mobilization in Wistar rats. Br J Pharmacol Toxicol 2012;3:110-14.

10. Ayinde BA, Owolabi OJ, Jesuorobo R. Active ileum relaxant fractions from the leaves of Ficus capensis Thunb (Moraceae). Niger J Pharm Sci 2013;12:1-7.

11. Ramde-Tiendrebeogo A, Tibiri A, Hilou A, Lomp M, Millogo-Kone $\mathrm{H}$, Nacoulma OG, et al. Antioxidative and antibacterial activities of phenolic compounds from Ficus sur Forssk. and Ficus sycomorus L. (Moraceae): Potential for sickle cell disease treatment in Burkina Faso. Int J Biol Chem Sci 2012;6:328-36.

12. Gelfand $M$, Mavi $S$, Drummond RB, Ndemera B. The Traditional Medicinal Practitioner in Zimbabwe. Gweru: Mambo Press; 1985. p. 411

13. Musa DA, Lifebuoy DG, Cyril O, Okwesili FC. Phytochemical and in vitro anti-typhoid properties of leaf, stem and root extracts of Ficus capensis (Moraceae). J Pharm Bioresour 2019;16:165-172.

14. Ogbiko C, Eboka CJ, Tambuwal AD. Extraction and fractionation of whole black seed plantain (Plantago rugelii Decne) for in-vitro antioxidant, antibacterial and phytochemical screening. J Appl Sci Environ Manage 2018;22:613-8.

15. Motaleb MA. Selected Medicinal Plants of Chittagong Hill Tracts. Gland, Switzerland: International Union of Conservation of Nature and Natural Resources; 2011. p. 1-3.

16. Holt JG, Krieg NR, Sneath PA. Bergey's Manual of Systematic Bacteriology. $9^{\text {th }}$ ed. Baltimore Maryland: Williams \& Wilkins Co.; 1994. p. 786.

17. Chessbrough M. District Laboratory Practice in Tropical Countries. $2^{\text {nd }}$ ed. London: Cambridge University Press; 2006. p. 21.

18. Musa AD, Nwodo OF, Ojogbane EB. Phytochemical, antibacterial and toxicity studies of the aqueous extract of Euclayptus camaldulensis Dehnh. Asian J Plant Sci Res 2011;1:1-10.

19. Musa AD, Dorgu S, Markwalder R, Oshe AO, Kanki H, Nwodo OF, et al. In vitro antibacterial activities of crude and partially purified fractions of defatted ethanol extract of Ficus capensis. Biokemistri 2017;29:67-75.

20. Arthington-Skaggs $B A$, Lee-Yang W, Ciblak MA, Frade JP, Brandt ME, Rana $A$, et al. Comparison of visual and spectrophotometric methods of broth microdilution, MIC, End Point determination and evaluation of a sterol quantitation method for in vitro susceptibility testing of fluconazole and itraconazole against trailing and non trailing candida isolates. Antimicrob Agents Chemother 2012;46:2477-81.

21. Cooper J, Niggli U, Leifert C. Handbook of Organic Food Safety and Quality. Cambridge, England: Woodhead Publishing Limited Abington Hall Abington; 2006. p. 34.

22. Uzoekwe NM, Mohammed JJ. Phytochemical, proximate and mineral contents of leaves and Bark of Ficus capensis. J Appl Sci Environ Manage 2015;19:633-7.

23. Alli S. Determination of chemical composition of Senna siamea (Cassia leaves). Pak J Nutr 2009;8:119-21.

24. Mohammed A, Liman ML, Atiku MK. Chemical composition of the methanolic leaf and stem bark extracts of Senna siamea Lam. J Pharmacogn Phytother 2013;5:98-100.

25. Ahmad-Alizaga SL, Olayanju S. Phytochemical screening of the leaf extracts of Senna siamea Lam (Pop corn) and its antibacterial activity. Biol Environ Sci J Trop 2007;4:193-5.

26. Doughari $\mathrm{JH}$, Okafor NB. Antibacterial activity of Senna siamea leaf extracts on Salmonella typhi. Afr J Microbiol Res 2008;2:42-6.

27. François MN, Amadou D, Rachid S. Chemical composition and biological activities of Ficus capensis leaves extracts. J Natl Prod 2010;3:147-60.

28. Solomon-Wisdom GO, Shittu GA, Agboola YA. Antimicrobial and phytochemical screening activities of Ficus sur (Forssk). N Y Sci J 2011;4:15-8 